\title{
Peran Brand Trust dan Brand Reputation dalam Menguatkan Pengaruh Brand Awareness terhadap Brand Performance Kasus pada Langit Musik
}

\section{The Role of Brand Trust and Brand Reputation in Strengthening the Influence of Brand Awareness on Brand Performance Cases on Langit Musik}

\author{
Teguh Widodo* \\ Program Studi Manajemen Telekomunikasi dan Informatika, Fakultas Ekonomi dan Bisnis, Universitas Telkom, Jalan \\ Telekomunikasi No. 1, Bandung \\ e-mail: teguhwi@telkomuniversity.ac.id \\ Dheana Rakhmawati \\ Program Studi Manajemen Telekomunikasi dan Informatika, Fakultas Ekonomi dan Bisnis, Universitas Telkom, Jalan \\ Telekomunikasi No. 1, Bandung \\ e-mail: dheanar99@gmail.com
}

\begin{abstract}
This study aims to analyze the factors that affect the brand performance of Langit Musik service with brand awareness as an exogenous variable. Brand awareness is hypothesized to affect brand performance either directly or indirectly. The entire hypothesis proposed forms a research framework in the structural equations (SEM) model. Empirical data was obtained through an online survey of 238 respondents who answered 24 questionnaire questions in full. The selection of respondents was determined by a non-probability sampling approach from users who have used and are using Langit Musik service in Indonesia. The software used to perform a series of statistical tests informs that all indicators used meet the criteria of validity and reliability, the research model meets the match criteria, the seven hypotheses submitted, the whole is accepted based on the t-significance test, and produces strong factors. The three variables and their expansion have a positive and significant effect on brand performance. The biggest influence of variables on consecutive brand performance is brand awareness, brand reputation, brand trust. To improve performance, Langit Musik can increase its promotion so that people can get to know langit musik service. The next study is expected to expand the variables one of which is purchase decisions placed after the brand performance variable in order to improve the hypothesis of the model.
\end{abstract}

Keywords: Brand awareness, brand trust, brand reputation, brand performance, structural equation modeling.

\begin{abstract}
ABSTRAK
Penelitian ini bertujuan untuk menganalisis faktor-faktor yang mempengaruhi brand performance dari layanan Langit Musik dengan brand awareness sebagai variabel eksogen. Brand awareness dihipotesiskan mempengaruhi brand performance baik secara langsung maupun tidak langsung. Keseluruhan hipotesis yang diajukan membentuk sebuah kerangka penelitian dalam model persamaan struktural (SEM). Data empirik didapatkan melalui survey online terhadap 238 responden yang menjawab 24 butir pertanyaan kuesioner secara lengkap. Pemilihan responden ditentukan dengaan pendekatan non-probability sampling dari pengguna yang pernah menggunakan dan sedang menggunkan layanan Langit Musik di Indonesia. perangkat lunak yang digunakan untuk melakukan serangkaian pengujian statistik menginformasikan bahwa seluruh indikator yang digunakan memenuhi kriteria validitas dan reliabilitas, model penelitian memenuhi kriteria kecocokan, tujuh hipotesis yang diajukan, keseluruhannya diterima berdasarkan uji signifikansi-t, serta menghasilkan faktor yang kuat. Ketiga variabel dan perluasannya berpengaruh positif dan signifikan terhadap brand performance. Pengaruh terbesar variabel pada brand performance berturut turut adalah brand awareness, brand reputation, brand trust. Untuk meningkatkan performa, Langit Musik dapat meningkatkan promosi nya agar masyarakat dapat lebih mengenal layanan Langit Musik ini. Penelitian berikutnya diharapkan memperluas variabel salah satunya purchase decision yang ditempatkan setelah variabel brand performance agar dapat menyempurnakan hipotesis model tersebut.
\end{abstract}

Kata kunci: Brand awareness, brand trust, brand reputation, brand performance, structural equation modeling. 


\section{PENDAHULUAN}

Pengguna internet Indonesia tahun 2019 sebanyak 196,71 juta jiwa yang menggunakan internet dimana populasi dari penduduk Indonesia sebanyak 266,91 juta jiwa, kenaikan pengguna internet dari tahun sebelumnya sebesar 8,9 persen atau setara dengan 25,5 juta pengguna internet yang bertambah pengguna (Asosiasi Penyelenggara Jasa Internet, 2020). Over The Top (OTT) merupakan jenis layanan berbentuk platform yang menyediakan sebuah konten melalui internet dan membutuhkan jaringan bagi pelanggan yang akan mengaksesnya. Dalam pelayanannya, OTT akan menyediakan berbagai jenis layanan dimulai dari perencanaan, penjualan, penyediaan atau servis. Selain itu, penyedia OTT juga dapat dikatakan sebagai penyedia layanan internet dengan konten melalui internet tanpa pengawasan langsung dari perusahaan telekomunikasi yang merupakan penyedia layanan komunikasi (Limbach, 2014; Putuhena, 2019).

Salah satu contoh OTT adalah layanan streaming music, dengan adanya layanan tersebut dan memiliki kemudahan pengaksesan akan memberikan banyak keuntungan, memajukan penjualan, memberikan inovasi dan kemudahan, hingga berpotensi mengurangi musik bajakan (Aguiar, 2017; Putuhena, 2019). Sebanyak 15 persen pengguna internet yang mengunjungi konten musik online, streaming music online berada di posisi ketiga dalam kategori konten hiburan yangpaling banyak diakses. Music streaming market semakin meningkat setiap tahunnya hingga 2025 grafiknya terus meningkat dimana hal tersebut mengungkapkan bahwa industri musik akan terus berkembang (Statista, 2020). Indonesia memilki juga memiliki streaming platform bernama Langit Musik yang dikelola oleh PT. Melon Indonesia. Langit Musik berdiri sejak 2010, sudah beropraasi selama kurang lebih 1 tahun. Langit Musik menyediakan lebih dari 7 juta lagu, 30 persen dari banyak musisi Indonesia serta 70 persen dari lagu internasional. Serta terdapat banyak genre yang di kategorikan oleh Langit Musik beberapa diantaranya: religius, dangdut, rock, tradisional, indie, dll.

Dilakukannya perbandingan menggunakan data yang diakses dari SimilarWeb terdapatnya total visit Langit Musik selama 6 bulan terakhir dimana terdapat kenaikan pada bulan Agustus sebanyak 1,4 juta pengunjung, kemudian pada bulan Oktober terjadi penurunan total pengunjungmenjadi 640 ribu dan pada bulan Desember terjadi kenaikan total pengunjung menjadi 740 ribu. Selain itu, rata rata pengunjung mengunjungi layanan Langit Musik sekitar 1 menit 9 detik. Jugaterdapat page per visit dari Langit Musik yaitu 2,23, dan dapat dilihat bounce rate pada Langit Musik sebesar 67,30 persen dimana angka tersebut untuk bounce rate Langit Musik cukup tinggi. Disamping itu, total visit pada Joox dan Spotify pada 6 bulan terakhir dimana Joox untuk bulan Agustus memiliki total visit sebanyak 5,6 juta pengunjung dan pada bulan Oktober total pengunjung mengalami penurunan menjadi 4,8 juta, kemudian pada bulan Desember mengalamikenaikan menjadi 6,6 juta total pengunjung. Dimana rata-rata pengunjung mengungjungi Joox selama 4 menit 25 detik, Juga page per visit dari Joox yaitu 2,82 dan bounce rate pada Joox sebesar 49,07 persen. Disamping itu, pada Spotify untuk bulan Agusts total pengunjungnya sebanyak 305 juta pengunjung lalu pada bulan November mengalami kenaikan menjadi 320 juta total pengunjung dan pada bulan Desember terjadi kenaikan lagi menjadi 379,5 juta pengunjung yang mengunjungi Spotify, kemudian dapat dilihat rata-rata pengunjung mengunjungi Spotify sebanyak 4 menit 8 detik lalu pada page per visit pada Spotify yaitu 5,33. Juga terdapat bounce rate pada Spotify sebesar 40,05 persen.

Di samping itu, Langit Musik sendiri sudah berdiri selama lebih dari 10 tahun akan tetapi masyarakat sendiri masih kurang mengetahui mengenai Langit Musik. Kemudian terdapatnya beberapa keluhan pada kolom ulasan Langit Musik pada media App Store. Beberapa keluhan yang terdapat dikolom komentar tersebutjuga memiliki indikasi terhadap variabel-variabel yang akan digunakan. Selain itu juga ditemukannya research gap (celah penelitian) terdahulu yang memiliki hasil yang saling bertentangan. Dimana pada penelitian terdahulu yang dilakukan oleh Foroudi (2019) ditemukannya celah penelitian antara brand awareness terhadap brand reputation, sedangkan penelitian yang dilakukan oleh Han et al. (2015) dan Thakshak (2018) dimana ditemukan pengaruh positif antara brand awareness terhadap brand reputation. Sehingga, peneliti mengusulkan menambahkan brand trust sebagai variabel mediasi yang 
diletakkan antara variabel brand awareness dan brand reputation guna untuk memperkuat hubungan variabel tersebut. Berdasarkan fenomena bisnis dan research gap diatas, menunjukkan bahwa rendahnya brandperformance pengguna layanan Langit Musik yang dipengaruhi oleh brand awareness, brand trust, brand reputation. Perlu dilakukannya pengujian ulang secara empirik pengaruh antara variabel-variabel tersebut terhadap brand performance, serta bagaimana peran variabel-variabel mediasi tersebut dalam memperkuat pengaruh brand awareness terhadap brand performance. Oleh karena itu, peneliti terdorong untuk melakukan sebuah penelitian dengan judul "Peran Brand Trust Dan Brand Reputation Dalam Menguatkan Pengaruh Brand Awareness Terhadap Brand PerformanceKasus Pada Langit Musik".

\section{Tinjauan Pustaka}

\section{Brand Awareness dan Brand Trust}

Brand awareness adalah persepsi pelanggan potensial untuk mengenali atau mengingat bahwa suatu merek merupakan komponen dari kategori produk tertentu (Liu et al., 2020; Aaker, 1991). Kemudian, dia juga menegaskan bahwa kesadaran secara umum dapat ditingkatkan dari tidak adanya kesadaran menjadi tahap pengenalan untuk mengingat ke top-of-mind. Dalam Penelitian terdahulu menyatakan bahwa brand awareness dapat menempatkan sebuah merek dalam perangkat pertimbangan dan meningkatkan keunggulan pilihan (Liu et al., 2020; Aaker, 1991; Keller, 2003). Dalam studi empiris menunjukkan bahwa brand awareness dapat mempengaruhi pilihan merek dan pangsa pasar di masa mendatang (Liu et al., 2020; Srinivasan., 2005). Keuntungan dari memiliki nama merek dalam suatu bisnis akan mengurangi risiko kehilangan pendapatan dan pelanggan membeli jasa pesaing (Thakshak, 2018; Bharadwaj, Varadarajan, \& Fahy, 1993 et al.). Disamping itu, brand awareness harus dikaitkan dengan "loyalitas perilaku" ketika keterlibatan rendah dengan internalisasi yang kuat (Liu et al., 2020; Dick \& Basu,1994).

\section{H1: Brand awareness berpengaruh positif dan signifikan terhadap brand trust}

\section{Brand Trust dan Brand Reputation}

Brand trust adalah elemen keberhasilan utama untuk sebagian besar hubungan profesional, bisnis, dan pemangku kepentingan (Rezvani et al., 2018; Pinto et al., 2009). Brand trust juga merupakan keyakinan dan kepercayaan terutama berasal dari psikologi sosial, yang menyatakan bahwa interaksi antara orang-orang dan reaksi kognitif-emosional terhadap interaksi akan menentukan perilaku kepercayaan dan merupakan keyakinan bahwa jika janji orang lain dapat dipercaya, sebuah keyakinan juga dapat disamakan dengan arti keamanan (Kusumawati \& Widodo, 2018; Suh \& Han, 2002). Adanya sikap Trust tersebut hadir melalui pengalaman dan kegiatan bersama dan merupakan konsep yang diperlukan untuk hubungan yang sukses antara perusahaan dan pelanggannya (Chae et al., 2020; Anderson \& Narus, 1990). Brand trust sebagai kepercayaan di mana toko yang dipilih oleh konsumen akan membawa manfaat terbaik bagi mereka (Chae et al., 2020; Choi, 2012). Munculnya sikap kepercayan terhadap sesuatu dapat meningkatkan kemungkinan dalam konsumen akan memilih produk mereka (Chae et al., 2020; Erdem \& Swait, 2004).

$\mathrm{H} 2$ : Brand trust berpengaruh positif dan signifikan terhadap brand reputation

\section{Brand awareness, brand trust, brand reputation and brand performance}

Kebutuhan untuk menghasilkan kredibilitas merek dan meningkatkan intensitas loyalitas di antara pelanggan berasal dari kesadaran merek (Thakshak, 2018). Brand awareness dianggap sebagai komponen utama reputasi (Han et al., 2015; Davies \& Miles, 1998), dan investasi dalam brand awareness dapat mengarah pada keunggulan kompetitif yang berkelanjutan dan nilai merek jangka panjang (Macdonald \& Sharp, 2003). Memiliki brand reputation yang kuat sangat penting bagi perusahaan yang ingin menciptakan keunggulan berkelanjutan atas pesaing mereka (Ryan, 
Kepercayaan konsumen terhadap merek khusus sehingga meningkatkan reputasi merek. Brand image dan brand reputation berfungsi sebagai isyarat eksternal yang kritis, karena dapat memandu konsumen ketika mengevaluasi suatu produk, yang pada gilirannya dapat memengaruhi niat beli (Ryan, 2018; Boulding \& Kirmani, 1993). Brand performance adalah ukuran relatif dari kesuksesan merek (Molinillo et al., 2019; Ehrenberg, Uncles, \& Goodhardt, 2004). Selain itu, langkah-langkah brand performance memungkinkan brand managers untuk memahami nilai merek dan membandingkan kesuksesan merek di berbagai pasar (Molinillo et al., 2019; Chapman, 1993). Brand reputation adalah aset strategis yang mengarah pada performance yang baik (Wu, 2015; Park, Jaworski, \& MacInnis, 1986). Brand reputation yang bersifat abadi akan menguntungkan juga hal tersebut dapat memastikan brand performance yang menguntungkan juga, serta dapat mengembangkan sikap positif dalam organisasi (Foroudi, 2019; Van Riel, 1995; Van Riel \& Balmer, 1997). Brand reputation tidak selalu menjadi katalisator untuk penjualan dan peningkatan laba. Hal tersebut dapat menjadi konsekuensi dari peningkatan brand performance saat ini atau pada masa depan dimana hal tersebut dapat meningkatkan brand loyalty, brand re-purchase, dan brand recommendation (Foroudi, 2019; Van Riel, 1995; Van Riel \& Balmer, 1997).

$\mathrm{H} 3$ : Brand reputation berpengaruh positif dan signifikan terhada brand performanceH4 : Brand trust berpengaruh positif dan signifikan terhadap brand performance

H5 : Brand awareness berpengaruh positif dan signifikan terhadap brand performance

H6 : Brand awareness berpengaruh positif dan signifikan terhadap brand performance secaratidak langsung.

H7 : Brand awareness berpengrauh positif dan signifikan terhadap brand reputation secaratidak langsung

4. Kerangka Penelitian

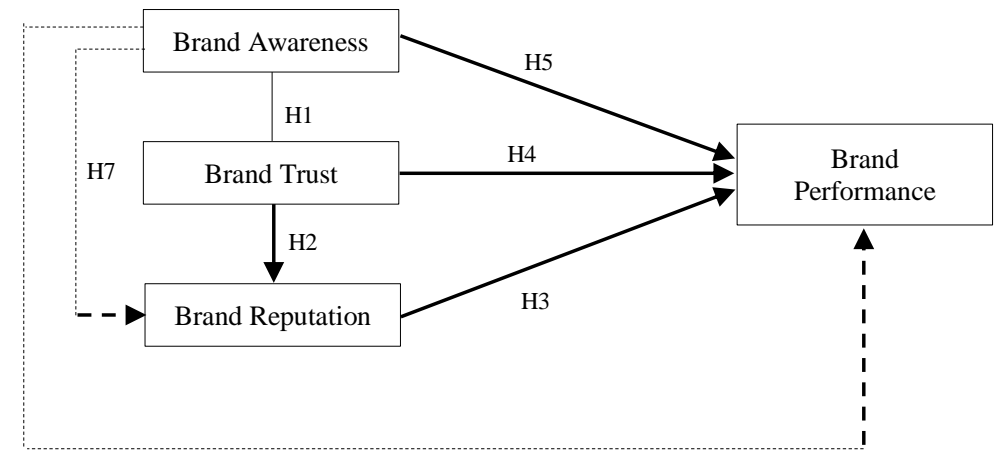

Gambar 1. Kerangka Penelitian

5. Operasionalisasi Variabel

Berikut tabel operasional variabel yang menggambarkan dari masing-masing variabel: 
Tabel 1. Variabel dan Indikator Penelitian

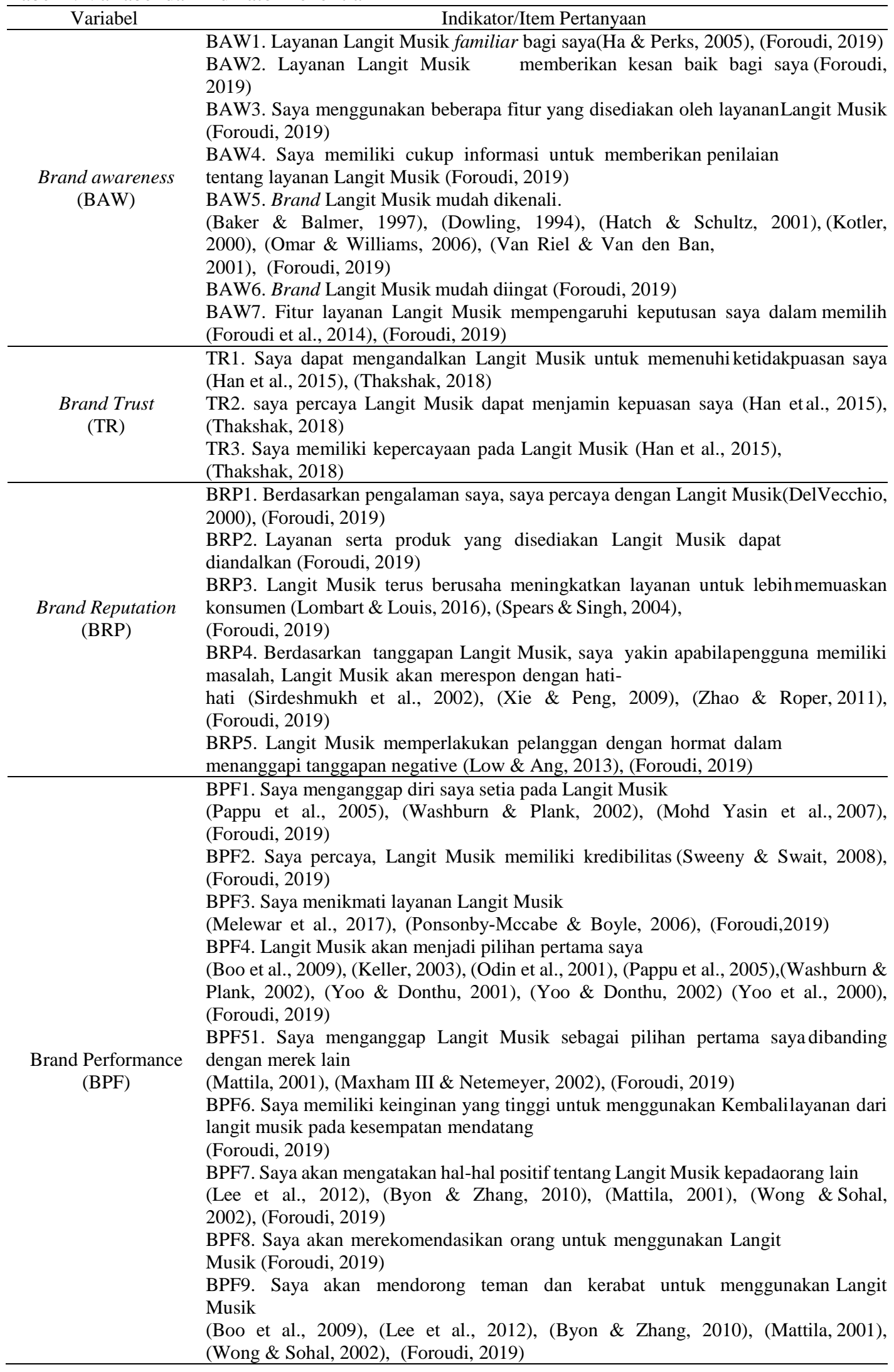

Penelitian ini menggunakan non-probability sampling, dan menggunakan metode convenience sampling yaitu dengan mengambil sampel yang tersedia dan memungkinkan 
untuk memberikan sebuah informasi bagi peneliti (Bryman \& Bell, 2011:190). Populasi yang dipilih dalam penelitian ini adalah orang-orang yang menggunakan atau sudah pernah menggunakan layanan Langit Musik. Skala likert yang digunakan untuk mengukur penelitian ini memiliki 5 indikator adri mulai "sangat tudak setuju" hingga "sangat setuju" serta model penelitian yang digunakan menggunakan structural equation modeling (SEM). Penelitian ini menggunakan teknik analisis structural equation modeling (SEM), SEM paling cocok digunakan ketika peneliti memiliki banyak variabel yang dipresentasikan dengan beberapa indikator dan variabel-variabel tersebut dapat dibedakan menjadi variabel eksogen dan endogen (Hair et al, 2010:641) dan diolah menggunakan software LISREL 8.8 dimana program LISREL 8.80 tersebut yang paling sering digunakan dalam melakukan metode SEM (Hair et al., 2010 p.632).

\section{HASIL DAN PEMBAHASAN}

\section{Uji Validitas dan Reliabilitas}

Pada penelitian kali ini dilakukannya uji validitas dimana untuk memastikan bahwa pengujian validitas dilakukan menggunakan Confirmator Factor Analysis (CFA), yaitu untuk mengamati loading factor pada setiap indikator. Apabila loading factor dihasilkan lebih besar dari 0.5, maka dapat dikatan valid dan sesuai (Hair et al., 2010). Kemudian menggunakan Average Variance Extracted (AVE) untuk melakukan uji validitas di penelitian ini, dengan nilai AVE diatas adalah 0.5 yang menunjukkan indikator-indikator pada suatu variabel yang sudah menyatu dan mewakili variabel tersebut (Ramadhani \& Widodo, 2019). Nilai CR pada variabel yang lebih besar sama dengan 0.7 menunjukkan nilai reliabilitas yang baik, tetapi nilai CR diantara 0.6 sampai 0.7 dapat diterima jika memiliki nilai construct validity yang tinggi. Nilai CR yang tinggi menunjukkan indikator-indikator pada suatu variabel yang secara konsisten untuk mempresentasikan variabel tersebut (Hair et al., 2010).

Tabel 2. Valid dan Reliabel

\begin{tabular}{|c|c|c|c|c|c|}
\hline Variabel & Indikator & $\begin{array}{c}\text { Std. } \\
\text { LoadingFactors }\end{array}$ & $\begin{array}{r}\text { Error } \\
\text { Variance }\end{array}$ & $\begin{array}{l}\text { Construct } \\
\text { Reliability }\end{array}$ & $\begin{array}{c}\text { Avg. Variance } \\
\text { Ectracted }\end{array}$ \\
\hline \multirow{7}{*}{ BAW } & BAW1 & 0,70 & 0,51 & \multirow{7}{*}{$\begin{array}{c}0,92 \\
\text { (Reliabel) }\end{array}$} & \multirow{7}{*}{$\begin{array}{c}0,61 \\
\text { (Valid) }\end{array}$} \\
\hline & BAW2 & 0,78 & 0,39 & & \\
\hline & BAW3 & 0,81 & 0,34 & & \\
\hline & BAW4 & 0,79 & 0,37 & & \\
\hline & BAW5 & 0,81 & 0,35 & & \\
\hline & BAW6 & 0,75 & 0,44 & & \\
\hline & BAW7 & 0,83 & 0,31 & & \\
\hline \multirow{3}{*}{ TR } & TR1 & 0,92 & 0,16 & \multirow{3}{*}{$\begin{array}{c}0,90 \\
\text { (Reliabel) }\end{array}$} & \multirow{3}{*}{$\begin{array}{c}0,76 \\
\text { (Valid) }\end{array}$} \\
\hline & TR2 & 0,88 & 0,23 & & \\
\hline & TR3 & 0,81 & 0,34 & & \\
\hline \multirow{5}{*}{ BRP } & BRP1 & 0,60 & 0,64 & \multirow{5}{*}{$\begin{array}{c}0,84 \\
\text { (Reliabel) }\end{array}$} & \multirow{5}{*}{$\begin{array}{c}0,52 \\
\text { (Valid) }\end{array}$} \\
\hline & BRP2 & 0,71 & 0,49 & & \\
\hline & BRP3 & 0,77 & 0,40 & & \\
\hline & BRP4 & 0,78 & 0,40 & & \\
\hline & BRP5 & 0,74 & 0,46 & & \\
\hline \multirow{9}{*}{ BPF } & BPF1 & 0,69 & 0,51 & \multirow{9}{*}{$\begin{array}{c}0,93 \\
\text { (Reliabel) }\end{array}$} & \multirow{9}{*}{$\begin{array}{c}0,59 \\
\text { (Valid) }\end{array}$} \\
\hline & BPF2 & 0,73 & 0,44 & & \\
\hline & BPF3 & 0,66 & 0,54 & & \\
\hline & BPF4 & 0,77 & 0,40 & & \\
\hline & BPF5 & 0,83 & 0,31 & & \\
\hline & BPF6 & 0,86 & 0,26 & & \\
\hline & BPF7 & 0,84 & 0,30 & & \\
\hline & BPF8 & 0,75 & 0,43 & & \\
\hline & BPF9 & 0,74 & 0,45 & & \\
\hline
\end{tabular}

Berdasarkan Tabel 1 yang tertera diatas uji validitas dan reliabilitas pada penelitian ini dapat dilakukan dengan menggunakan rumus Construct Reliability (CR) dan Average Variance

Jurnal Manajeme an Organisasi (JMO), Desember 2021, Hal. 189-201 
Extracted (AVE). Dari tabel yang tertera di atas dapat dilihat bahwa loading factor yang tertera pada setiap indikator memiliki nilai diatas 0,5 , dimana seluruh indikator tersebut telah sesuai untuk mengukur setiap variabelnya masing-masing. Setelah itu, dilakukannya uji reliabilatas dengan menggunakan rumus dari CR dimana nilai CR dari setiap variabel dinyatakan reliabel. Kemudian, peneliti melakukan uji validitas dengan menggunakan rumus dari AVE yang dimana nilai AVE dari setiap variabel dinyatakan valid.

Tabel 3. Goodness of Fit pada Model Struktural

\begin{tabular}{|c|c|c|c|}
\hline Goodness of Fit Indices & Cut-Off Value & Hasil Penelitian & Tingkat Kecocokan \\
\hline \multicolumn{4}{|c|}{ Absolute Fit Indices } \\
\hline$X^{2}$ Significance Probability & $\geq 0,05$ & $\mathrm{P}=0,00$ & Poor Fit \\
\hline GFI & $\geq 0,90$ & 0,83 & Marginal Fit \\
\hline RMSEA & $\leq 0,08$ & 0,068 & Goof Fit \\
\hline$R M R$ & $\leq 0,08$ & 0,050 & Good Fit \\
\hline$S R M R$ & $\leq 0,08$ & 0,050 & Good Fit \\
\hline Nor. Chi-Square $(\chi 2 / D F)$ & $<3$ & 1,92 & Good Fit \\
\hline \multicolumn{4}{|c|}{ Incremental Fit Indices } \\
\hline NFI & $\geq 0,90$ & 0,96 & Good Fit \\
\hline TLI (NNFI) & $\geq 0,90$ & 0,97 & Good Fit \\
\hline$C F I(R N I)$ & $\geq 0,90$ & 0,98 & Good Fit \\
\hline$R F I$ & $\geq 0,90$ & 0,95 & Good Fit \\
\hline IFI & $\geq 0,90$ & 0,98 & Good Fit \\
\hline \multicolumn{4}{|c|}{ Parsimony Fit Indices } \\
\hline$A G F I$ & $\geq 0,90$ & 0,80 & Poor Fit \\
\hline PNFI & $\geq 0,50$ & 0,86 & Good Fit \\
\hline PGFI & $\geq 0,50$ & 0,69 & Good Fit \\
\hline
\end{tabular}

Berdasarkan Tabel 2 dan penjelasan yang tertera diatas, dapat kita ketahui bahwa model penelitian menghasilkan 2 ukuran GOF yang termasuk dalam kategori poor fit yang berari kecocokan kurang baik. Selain itu, terdapat 1 ukuran GOF yang termasuk dalam kategori marginal fit dan sisanya 11 ukuran GOF termasuk kedalam ukuran good fit yang berarti memiliki tingkat kecocokan yang baik. Sehingga dapat dikatakan tingkat kecocokan model pada penelitian ini sudah dalam keadaan good fit (Hair et al., 2010).

\section{Uji Hipotesis Persamaan Struktural}

Hubungan antar variabel yang terdapat pada suatu model penelitian akan membentuk suatu persamaan struktural (Widodo \& Octaviany, 2019). Penelitian ini menghasilkan tiga persamaan struktural, sebagai berikut:

$$
\mathrm{TR}=0,64 * \mathrm{BAW}, \text { Errorvar }=0,59, \mathrm{R}^{2}=0,41
$$

Persamaan diatas menunjukkan bahwa variabel brand trust dipengaruhi oleh brand awareness. Brand awareness (BAW) berpengaruh signifikan dan positif terhadap brand trust (TR), T-Value pada hubungan ini sebesar 9,01 yang berarti lebih besar dari 1,96 (T-tabel). Selain itu, seperti yang dapat dilihat bahwa koefisien regresinya sebesar 0,64 . Nilai $\mathrm{R}^{2}$ yang terdapat diatas sebesar 0,41 , hal tersebut mengartikan bahwa 41 persen dari TR sudah dapat dijelaskan melalui variabel brand awareness, sedangkan untuk 59 persen sisanya dijelaskan dengan error variance, dimana hal tersebut terdapatnya kemungkinan bahwa variabel lain yang dapat menjelaskan TR. Semakin tinggi tingkat kesadaran pengguna langit musik maka semakin tinggi trust.

$\mathrm{BRP}=0,69 * \mathrm{TR}$, Errorvar $=0,53, \mathrm{R}^{2}=0,47$ 
Pada persamaan diatas menunjukkan bahwa variabel brand reputation (BRP) dipengaruhi oleh brand trust (TR). Brand trust (TR) berpengrauh signifikan dan positif terhadap brand reputation (BRP), T-Value pada hubungan ini sebesar 7,25 yang berarti lebih besar dari 1,96 (Ttabel). Selain itu, dapat dilihat bahwa koefisien regresinya sebesar 0,69 Nilai $\mathrm{R}^{2}$ yang terdapat sebesar 0,47 , hal tersebut mengartikan bahwa 47 persen dari brand reputation (BRP) sudah dapat dijelaskan melalui brand trust (TR), sedangkan untuk 53 persen sisanya dijelaskan dengan error variance, dimana hal tersebut terdapatnya kemungkinan bahwa variabel lain dapat mempengaruhi.

$$
\mathrm{BPF}=0,25 * \mathrm{TR}+0,27 * \mathrm{BRP}+0,46 * \mathrm{BAW}, \text { Errorvar }=0,30, \mathrm{R}^{2}=0,70
$$

Pada persamaan struktural diatas dapat dilihat bahwa variabel brand performance (BPF) dipengaruhi oleh brand trust (TR), brand reputation (BRP) dan brand awareness (BAW). Hubungan antar variabel signifikan dan positif dengan koefisien regresi pada masing-masing variabel yang tertera sebelum nama variabel. Terdapatnya pengaruh variabel brand trust (TR) terhadap brand performance (BPF) yang positif dan signifikan dengan T-Value pada hubungan ini sebesar 2,80 yang berarti leih dari 1,96 (T-tabel) selain itu, dapat dilihat dari nilai koefisien regresinya yaitu sebesar 0,25 .

Pada variabel brand reputation (BRP) terhadap brand performance (BPF) yang positif dan signifikan memiliki T-Value pada hubungan ini sebesar 3,30 yang berarti lebih besar dari 1,96 (T-tabel) serta terdapatnya nilai koefisien regsinya sebesar 0,27. Kemudian, terdapat pengaruh yang positif dan signifikan pada variabel brand awareness (BAW) terhadap brand performance (BPF)dimana memiliki T-Value sebesar 5,98 yang berarti lebih dari 1,96 (T-tabel) dan nilai koefisien regresi yang didapat sebesar 0,46 Selain itu terdapat $\mathrm{R}^{2}$ yang tertera bernilai 0,70 bermakna bahwa 70 persen dari BPF sudah dijelaskan melalui variabel-varaibel yang mempengaruhi BPF. Dalampenelitian ini juga terdapat error variance yang bernilai 0,30 yang berarti bahwa varaibel lain yang dapat mempengaruhi brand performance (BPF) yaitu sebesar 30 persen. Berdasarkan hasil penelitian yang dilakukan, hipotesis yang di dapat sebagai berikut:

\section{Pengujian Hipotesis Hubungan Langsung}

Penelitian ini mengajukan tujuh hipotesis, lima diantaranya berupa hipotesis hubungan langsung yang telah diuji dengan menggunakan uji-T yaitu membandingkan nilai-T dari hasil pengolahan data dengan nilai-T dari tabel yaitu sebesar 1,96 sebagai kriterianya. Jika nilai-T hasil perhitungan lebih besar dari 1,96 maka hipotesis diterima. Kelima uji hipotesis hubungan langsung tersebut disajikan pada Tabel 3 berikut ini:

Tabel 4. Uji Hipotesis Hubungan Langsung

\begin{tabular}{cccc}
\hline Hipotesis & Koefisien Regresi & T-Value & Hasil \\
\hline $\mathrm{H} 1: \mathrm{BAW}+\rightarrow \mathrm{TR}$ & 0,64 & 9,01 & H1 Diterima \\
$\mathrm{H} 2: \mathrm{TR}+\rightarrow \mathrm{BRP}$ & 0,69 & 7,25 & H2 Diterima \\
$\mathrm{H} 3: \mathrm{BRP}+\rightarrow \mathrm{BPF}$ & 0,27 & 3,30 & H3 Diterima \\
$\mathrm{H} 4: \mathrm{TR}+\rightarrow \mathrm{BPF}$ & 0,25 & 2,80 & H4 Diterima \\
$\mathrm{H} 5: \mathrm{BAW}+\rightarrow \mathrm{BPF}$ & 0,46 & 5,98 & H5 Diterima \\
\hline
\end{tabular}

Hasil pengujian hipotesis hubungan langsung menunjukkan bahwa seluruh hipotesis diterima. Brand awareness berpengaruh secara positif dan signifikan terhadap brand trust, dengan kata lain H1 diterima. Hal tersebut mengartikan bahwa apabila layanan Langit Musik dapat dikenal dengan baik oleh masyarakat maka kepercayaan yang muncul dari masyarakat pun semakin baik pula. Hal ini sesuai dengan hasil penelitian pada penelitian terdahulu yang menyatakan bahwa Brand Awareness berpengaruh posisitf dan signifikan terhadap Brand Trust oleh (Thakshak, 2018). Selanjutnya, variabel brand trust memiliki pengaruh positif dan signifikan terhadap variabel brand reputation dengan begitu dapat dikatakan bahwa penelitian 
$\mathrm{H} 2$ ini diterima. Hal tersebut mengartikan bahwa dengan adanya kepercayaan yang diciptakan oleh para pengguna terhadap Langit Musik hal tersebut dapat meningkatkan reputasi dari Langit Musik itu sendiri. Hal ini sesuai dengan hasil penelitian terdahulu yang menyatakan bahwa brand trust berpengaruh positif dan signifikan terhadap brand reputation oleh (Singh et al., 2020).

Hasil penelitian selanjutnya menunjukkan bahwa brand reputation berpengaruh secara positif dan signifikan terhadap brand performance dapat dikatakan bahwa $\mathrm{H} 3$ dalam penelitian ini diterima. mengartikan bahwa apabila reputasi dari Langit Musik baik, maka hal tersebut dapat mempengaruhi performa dari layanan Langit Musik itu sendiri. Hal ini sesuai dengan hasil penelitian terdahulu yang menyatakan bahwa brand reputation berpengaruh positif dan signifikan terhadap brand performance oleh (Foroudi, 2019).

Selanjutnya brand trust berpengaruh secara positif dan signifikan terhadap brand performance dengan begitu dapat dikatakan bahwa $\mathrm{H} 4$ dalam penelitian ini dapat diterima. Hal ini bermakna apabila kepercayaan yang telah dibangun oleh para pengguna layanan Langit Musik itu baik, maka hal tersebut dapat mempengaruhi seberapa baik performa dari layanan Langit Musik itu sendiri. Hal ini sesuai dengan hasil penelitian terdahulu yang menyatakan bahwa brand trust berpengrauh positif dan signifikan terhadap brand performance (Fan et al., 2021).

Brand awareness berpengaruh secara positif dan signifikan terhadap brand performance, sehingga dapat dikatakan bahwa $\mathrm{H} 5$ dalam penelitian ini dapat diterima. Hal tersebut mengartikan bahwa apabila layanan Langit Musik dapat diketahui serta dikenal dengan baik oleh masyarakat maka hal tersebut dapat berpengaruh pada performanya yang baik. Hal ini sesuai dengan hasil penelitian terdahulu yang menyatakan bahwa brand awareness berpengaruh positif dan signifikan terhadap brand performance (Kilei et al., 2016).

\section{Pengujian Hipotesis Hubungan Tidak Langsung}

Besarnya nilai-T dan koefisien regresi yang membentuk efek dekomposisi, digunakan untuk mengukur dan menampilkan efek langsung, efek tidak langsung dan efek total (Shara \& Widodo, 2018).

Tabel 5. Uji Hipotesis Hubungan Tidak Langsung

\begin{tabular}{cccc}
\hline Hipotesis & Koefisien Regresi & Nilai T & Keterangan \\
\hline $\mathrm{H} 6: \mathrm{BAW}+\rightarrow \mathrm{TR} \rightarrow \mathrm{BRP}$ & 0,44 & 5,88 & Diterima \\
$\mathrm{H} 7: \mathrm{BAW}+\rightarrow \mathrm{TR} \rightarrow \mathrm{BRP}$ & 0,28 & 5,08 & Diterima \\
$\rightarrow \mathrm{BPF}$ & & & \\
\hline
\end{tabular}

Hasil pengujian hipotesis hubungan tidak langsung menunjukkan bahwa hipotesis diterima. Hasil penelitian ini menunjukkan bahwa variable brand awareness memiliki pengaruh yang positif dan signifikan terhadap variable brand performance secara tidak langsung dengan melewati brand trust dan brand reputation sebagai variabel mediasinya, yang mengartikan apabila layanan Langit Musik dapat dikenal dan diketahui dengan baik oleh masyarakat dapat berpengaruh terhadap performa dari Langit Musik. Selain itu, dalam meningkatkan performanya dapat didukung oleh kepercayaan dari para pengguna serta reputasi dari layanan Langit Musik itu sendiri. Hal tersebut sesuai dengan penelitian (Kilei et al., 2016), dimana pada penelitian tersebut hubungan brand awareness terhadap brand performance menunjukkan indikasi yang berpengaruh positif dan signifikan dengan kata lain H6 dapat diterima.

Selanjutnya brand awareness berpengaruh secara positif dan signifikan terhadap brand reputation secara tidak langsung dengan melewati brand trust sebagai variabel mediasinya dengan begitu dapat dikatakan bahwa $\mathrm{H} 7$ dalam penelitian ini dapat diterima. Yang apabila layanan Langit Musik ini dapat dikenal dengan baik oleh masyarakat, maka dapat berpengaruh dengan peningkatan reputasi dari layanan Langit Musik tersebut. Selain itu, Langit Musik juga harus meningkatkan kepercayaan pada pengguna agar performa dari layanan Langit Musik ini dapat turut meningkat. Hal ini sesuai dengan hasil penelitian terdahulu yang menyatakan bahwa brand awareness berpengaruh positif dan signifikan terhadap brand reputation oleh (Thakshak, 


\section{KESIMPULAN}

Berdasarkan hasil analisis, kesimpulan yang dapat diambil dari penelitian ini adalah sebagai berikut: Variabel brand awareness berpengaruh secara positif dan signifikan terhadap brand trust dengan T-Value yang didapat sebesar 9,01 dan koefisien regresinya yang didapat sebesar 0,64. Variabel brand trust berpengaruh secara positif dan signifikan terhadap brand reputation dengan T-Value yang didapat sebesar 7,25 dan koefisien regresinya yang didapat sebesar 0,69. Variabel brand reputation berpengaruh secara positif dan signifikan terhadap brand performance dengan T-Value yang didapat sebesar 3,30 dan koefisien regresinya sebesar 0,27. Variabel brand trust berpengaruh secara positif dan signifikan terhadap brand performance dengan T-Value yang diperoleh sebesar 2,80 dan koefisien regresi yang didapat sebesar 0,25. Variabel brand awareness berpengaruh positif dan signifikan terhadap brand performance dengan T-Value yang diperoleh sebesar 5,98 dan koefisien regresi yang didapat sebesar 0.46. Variabel brand awareness berpengaruh positif dan signifikan terhadap brand performance secara tidak langsung dengan melewati brand trust dan brand reputation, diperolehnnya nilai-T yang sebesar 5,08 dan koefisien regresi yang didapat sebesar 0,28. Variabel brand awareness berpengaruh secara positif dan signifikan terhadap brand reputation secara tidak langsung dengan melewati brand trust sebagai variabel usulan pada penelitian ini, nilai-T yang diperoleh sebesar 5,88 dan koefisien regresinya sebesar 0,44.

\section{DAFTAR PUSTAKA}

Aguiar, L. (2017). Let the music play? Free streaming and its effects on digital music consumption. Information Economics and Policy, 41, 1-14. https://doi.org/10.1016/j.infoecopol.2017.06.002.

Baker, M. J., \& Balmer, J. M. T. (1997). Visual identity: Trappings or substance? European Journal of Marketing, 31(5/6), 366-382. https://doi.org/10.1108/eb060637.

Boo, S., Busser, J., \& Baloglu, S. (2009). A model of customer-based brand equity and its application to multiple destinations. Tourism Management, 30(2), 219-231. https://doi.org/10.1016/j.tourman.2008.06.003.

Bryman, A., \& Bell, E. (2011). Business Research Methods (3rd Edition). Oxford University: Press Inc.

Byon, K. K., \& Zhang, J. J. (2010). Development of a scale measuring destination image. Marketing Intelligence \& Planning, 28(4), 508532.https://doi.org/10.1108/02634501011053595.

Chae, H., Kim, S., Lee, J., \& Park, K. (2020). Impact of product characteristics of limited edition shoes on perceived value, brand trust, and purchase intention; focused on the scarcity message frequency. Journal of Business Research, S0148296319307179. https://doi.org/10.1016/j.jbusres.2019.11.040.

Davies, G., \& Miles, L. (1998). Reputation managenent: Theory versus practice. Corporate Reputation Review, 2(1), 16-27. https://doi.org/10.1057/PALGRAVE.CRR.1540064.

DelVecchio, D. (2000). Moving beyond fit: The role of brand portfolio characteristics in consumer evaluations of brand reliability. Journal of Product \& Brand Management, 9(7), 457-471. https://doi.org/10.1108/10610420010351411.

Dowling, G. R. (1994). Corporate reputations: Strategies for developing the corporate brand. Kogan Page.

Fan, J., Wei, X., \& Ko, I. (2021). How do hotel employees' feeling trusted and its differentiation shape service performance: The role of relational energy. International $\begin{array}{lllll}\text { Journal of } & \text { Hospitality } & \text { Management, } & 92, & 102700 .\end{array}$ https://doi.org/10.1016/j.ijhm.2020.102700.

Foroudi, P. (2019). Influence of brand signature, brand awareness, brand attitude, brand reputation on hotel industry's brand performance. International Journal of Hospitality Management, 76, 271-285. https://doi.org/10.1016/j.ijhm.2018.05.016. 
Foroudi, P., Melewar, T. C., \& Gupta, S. (2014). Linking corporate logo, corporate image, and reputation: An examination of consumer perceptions in the financial setting. Journal of Business Research, 67(11), 2269-2281. https://doi.org/10.1016/j.jbusres.2014.06.015.

Ha, H.-Y., \& Perks, H. (2005). Effects of consumer perceptions of brand experience on the web: Brand familiarity, satisfaction and brand trust. Journal of Consumer Behaviour, 4(6), 438- 452. https://doi.org/10.1002/cb.29.

Hair, J., Black, W. C., Babin, B. J., \& Anderson, R. E. (2010). Multivariate Data Analysis: A Global Perspektive (7th edition). Pearson Education Inc.

Han, S. H., Nguyen, B., \& Lee, T. J. (2015). Consumer-based chain restaurant brand equity, brand reputation, and brand trust. International Journal of Hospitality Management, 50, 84-93. https://doi.org/10.1016/j.ijhm.2015.06.010.

Hatch, M. J., \& Schultz, M. (2001). Are the strategic stars aligned for your corporate brand. Harvard Business Review, 79(2), 128-134.

Keller, K. L. (2003). Strategic Brand Management: Building, Measuring, and Managing Brand Equity.

Kilei, P., Iravo, D. M., \& Omwenga, D. J. (2016). The Impact Of Brand Awareness On Market Brand Performance Of Service Brands: Contextual Consideration of Kenya's Banking Industry. European Journal of Business and Management, 12.

Kotler, P. (2000). How to Create, Win and Dominate Market. Free Press.

Kusumawati, D., \& Widodo, T. (2018). Customer Intention Analysis of Use of Finpay Services Using Unified Theory of Acceptance and Use of Technology (UTAUT) Model (Study of Finpay Service User in Jakarta). International Journal of Research in Commerce, IT \& Management, 8(3), 1-6.

Lee, J., Kyle, G., \& Scott, D. (2012). The Mediating Effect of Place Attachment on the Relationship between Festival Satisfaction and Loyalty to the Festival Hosting Destination. Journal of Travel Research, 51(6), 754-767. https://doi.org/10.1177/0047287512437859.

Lombart, C., \& Louis, D. (2016). Sources of retailer personality: Private brand perceptions. Journal of Retailing and Consumer Services, 28, 117-125. https://doi.org/10.1016/j.jretconser.2015.09.002.

Low, P. K. C., \& Ang, S. L. (2013). Confucian Ethics, Governance and Corporate Social Responsibility. International Journal of Business and Management, 8(4). https://doi.org/10.5539/ijbm.v8n4p30.

Macdonald, E., \& Sharp, B. (2003). Management Perceptions of the Importance of Brand Awareness as an Indication of Advertising Effectiveness. 11.

Mattila, A. (2001). Emotional bonding and restaurant loyalty. The Cornell Hotel and Restaurant Administration Quarterly, 42(6), 73-79. https://doi.org/10.1016/S0010-8804(01)81012-0.

Maxham III, J. G., \& Netemeyer, R. G. (2002). A longitudinal study of complaining customers' evaluations of multiple service failures and recovery efforts. Journal of Marketing, 66(4), 57-71. https://doi.org/10.1509/jmkg.66.4.57.18512.

Melewar, T. C., Foroudi, P., Gupta, S., Kitchen, P. J., \& Foroudi, M. M. (2017). Integrating identity, strategy and communications for trust, loyalty and commitment. European Journalof Marketing, 51(3), 572-604. https://doi.org/10.1108/EJM-08-2015-0616.

Mohd Yasin, N., Nasser Noor, M., \& Mohamad, O. (2007). Does image of country-of-origin matter to brand equity? Journal of Product \& Brand Management, 16(1), 38-48. https://doi.org/10.1108/10610420710731142.

Molinillo, S., Ekinci, Y., \& Japutra, A. (2019). A consumer-based brand performance model for assessing brand success. International Journal of Market Research, 61(1), 93-110. https://doi.org/10.1177/1470785318762990.

Music Streaming -Indonesia | Statista Market Forecast. (n.d.). Statista. Retrieved November 20, 2020, from https://www.statista.com/outlook/209/120/music-streaming/indonesia.

Odin, Y., Odin, N., \& Valette-Florence, P. (2001). Conceptual and operational aspects of brand loyalty: An empirical investigation. Journal of Business Research, 53(2), 75-84. 
https://doi.org/10.1016/S0148-2963(99)00076-4.

Omar, M., \& Williams, R. L. (2006). Managing and maintaining corporate reputation and brand identity: Haier Group logo. Journal of Brand Management, 13, 268-275. https://doi.org/10.1057/palgrave.bm.2540270.

Pappu, R., Quester, P. G., \& Cooksey, R. W. (2005). Consumer-based brand equity: Improving the measurement - empirical evidence. Journal of Product \& Brand Management, 14(3), 143-154. https://doi.org/10.1108/10610420510601012.

Ponsonby-Mccabe, S., \& Boyle, E. (2006). Understanding brands as experiential spaces: Axiological implications for marketing strategists. Journal of Strategic Marketing, 14(2), 175-189. https://doi.org/10.1080/10427710600662983.

Putuhena, A. G. (2019). PERAN LAYANAN OVER-THE-TOP (OTT) PADA KONSUMEN MUSIK ILEGAL. 23(2), 14.

Ramadhani, Z. S., \& Widodo, T. (2019). Pengaruh Komunikasi Merek, Citra Merek, dan Kepercayaan Merek Terhadap Loyalitas Merek Smartphone Lenovo. Universitas Telkom.

Rezvani, A., Khosravi, P., \& Ashkanasy, N. M. (2018). Examining the interdependencies among emotional intelligence, trust, and performance in infrastructure projects: A multilevel study. International Journal of Project Management, 36(8), 1034-1046. https://doi.org/10.1016/j.ijproman.2018.08.002.

Ryan, J. (2018). The role of brand reputation in organic food consumption_ A behavioral reasoning perspective. Journal of Retailing and Consumer Services, 9.

Shara, P. V., \& Widodo, T. (2018). Penerapan Model Unified Theory Of Acceptance And Use Of Technology (UTAUT) Untuk Menganalisis Minat Pengguna Smartphone Di Kota Bandung.SOSIOHUMANITAS, 20(1). https://doi.org/10.36555/sosiohumanitas.v20i1.49.

SimilarWeb. Website Traffic Analysis \& Competitive Intelligence | SimilarWeb. SimilarWeb.Com. Retrieved January 27, 2021, from https://www.similarweb.com/

Singh, J., Crisafulli, B., Quamina, L. T., \& Xue, M. T. (2020). 'To trust or not to trust': The impact of social media influencers on the reputation of corporate brands in crisis. Journal of Business Research, S0148296320302034. https://doi.org/10.1016/j.jbusres.2020.03.039.

Sirdeshmukh, D., Singh, J., \& Sabol, B. (2002). Consumer Trust, Value, and Loyalty in Relational $\begin{array}{llll}\text { Exchanges. Journal of } & \text { Marketing, }\end{array}$ https://doi.org/10.1509/jmkg.66.1.15.18449.

Spears, N., \& Singh, S. N. (2004). Measuring Attitude toward the Brand and Purchase Intentions. Journal of Current Issues \& Research in Advertising, 26(2), 53-66. https://doi.org/10.1080/10641734.2004.10505164.

Sweeny, J., \& Swait, J. (2008). The effects of brand credibility on customer loyalty. Journal of Retailing and Consumer Services, 15(3), 179193.https://doi.org/10.1016/j.jretconser.2007.04.001.

Thakshak. (2018). Analysing customer based airline brand equity: Perspective from Taiwan. Future Business Journal, 4(2), 233-245. https://doi.org/10.1016/j.fbj.2018.07.001.

Van Riel, C. B. M., \& Van den Ban, A. (2001). Van Riel, C.B., Van den Ban, A., 2001. The added value of corporate logos-An empirical study. Eur. J. Mark. 35 (3/4), 428-440. European Journal of Marketing, 35(3/4), 428-440. https://doi.org/10.1108/03090560110382093.

Washburn, J. H., \& Plank, R. E. (2002). Measuring Brand Equity: An Evaluation of a ConsumerBased Brand Equity Scale. Journal of Marketing Theory and Practice, 10(1), 46-62. https://doi.org/10.1080/10696679.2002.11501909.

Wong, A., \& Sohal, A. (2002). An examination of the relationship between trust, commitment and relationship quality. International Journal of Retail \& Distribution Management, 30(1),34-50. https://doi.org/10.1108/09590550210415248.

$\mathrm{Wu}$, C.-W. (2015). Antecedents of franchise strategy and performance. Journal of Business Research, 68(7), 1581-1588. https://doi.org/10.1016/j.jbusres.2015.01.055.

Xie, Y., \& Peng, S. (2009). How to repair customer trust after negative publicity: The roles of competence, integrity, benevolence, and forgiveness. Psychology and Marketing, 26(7), 
572-589. https://doi.org/10.1002/mar.20289.

Yoo, B., \& Donthu, N. (2001). Developing and validating a multidimensional consumer-based brand equity scale. Journal of Business Research, 52(1), 1-14. https://doi.org/10.1016/S0148-2963(99)00098-3.

Yoo, B., \& Donthu, N. (2002). Testing cross-cultural invariance of the brand equity creation process. Journal of Product \& Brand Management, 11(6), 380-398.

Yoo, B., Donthu, N., \& Lee, S. (2000). An examination of selected marketing mix elements and brand equity. Journal of the Academy of Marketing Science, 28(2), 195-211. https://doi.org/10.1177/0092070300282002.

Zhao, L., \& Roper, J. (2011). A Confucian approach to well-being and social capital development. Journal of Management Development, 30(7/8),740-752. https://doi.org/10.1108/02621711111150245. 